\title{
Receptarea misionară a teologiei Părintelui Dumitru Stăniloae
}

Abstract: Romanian orthodox theology had a great chance to reborn in the full communist period, thanks to the genius monumental work of the father teacher Dumitru Stăniloae. Thanks to his extraordinary analysis and synthesis, the great theologian managed to put in dialogue the theological vision of Saints Fathers with the theological and philosophical thinking and also culturally contemporaneous, creating a paradoxical dogmatic theology neo-patristic and also a theological answer that is current and relevant, to the problems of life. Through his life and work, father Stăniloae managed to unite theology with life and erudition with godliness, highlighting the spiritual value of the tenets belonging to the Orthodox Church and thus their impact on the practical life of the Christianity. Thus dogmatic theology becomes an impressive missionary force, because it becomes, through Dumitru Stăniloae, an invitation addressed to the $3^{\text {rd }}$ millennium man to live in communion and

\footnotetext{
"PhD Candidate, Faculty of Orthodox Theology at „1 Decembrie 1918" University in Alba Iulia, Romania.
} 


\section{Alexandru TEOMPA}

dialogue with God and with others, the model of life of persons from the Trinity.

Keywords: patristic theology, erudition, spiritual rebirth, person, communion, philokalic vision

Teologia ortodoxă românească a avut marea şansă de a renaşte în plină perioadă comunistă, graţie operei monumentale a geniului său, părintele profesor Dumitru Stăniloae. Opera sa este deosebit de complexă şi completă, cuprinzând toate aspectele cercetării teologice: dogmatic, moral, mistico-ascetic, biblic, istoric, apologetico-misionar, pastoral şi liturgic. Esenţa teologiei sale constă în ceea ce teologii numesc: „Trilogia”: Dogmatică - Spiritualitate - Liturgica, ${ }^{2}$ prin care ,părintele Dumitru Stăniloae ocupă în Ortodoxia actuală o poziţie similară celei unui K. Barth în Protestantism şi K. Rahner sau mai degrabă H. Urs von Balthasar în catolicism"’3.

Părintele Stăniloae este puntea de legătură între teologia rusă, dezvoltată în Occident (prin teologii V. Lossky, G. Florovsky, J. Meyendorff, A. Schmemann, P. Evdokimov etc.) şi teologia greacă (reprezentată de Ch. Yannaras, N. Nissiotis, I. Zizioulas etc.), având o viziune teologică mai echilibrată şi mai deschisă spre dialog, în cadrul mişcării neo-patristice dezvoltate în secolul al XX-lea în teologia ortodoxă. Dacă la ceilalţi teologi găsim deseori abordări unilaterale sau derapaje teologice, susţinute cu multă patimă ${ }^{4}$, viziunea teologică

${ }^{2}$ Teologia dogmatică ortodoxă, în 3 volume, a apărut în 1978 (Bucureşti, EIBMBOR), Spiritualitatea ortodoxă. Ascetica şi mistica a apărut în 1981 (Bucureşti, EIBMBOR) iar Spiritualitate şi comuniune în liturghia ortodoxă, în 1986, (Craiova, Edit. Mitropoliei Olteniei), fiind operele de maturitate ale marelui teolog.

${ }^{3} \dagger$ Kallistos Ware, Experienţa lui Dumnezeu în „Teologia dogmatică” a părintelui Dumitru Stăniloae, în ***, Părintele Dumitru Stăniloae în conștiința contemporanilor. Mărturii, evocări, amintiri, Iaşi, Edit. Trinitas, 2003, p. 63.

${ }^{4}$ Diac. Asist. I. Ioan I. Ică jr., Persoană sau / şi ontologie în gândirea ortodoxă 
a părintelui Stăniloae e una complexă, amplă, caracterizată de mulţi teologi ca fiind ,sferică”. Teologul grec, Stelian Papadopoulos, sesizând această sfericitate a demersului teologic la Părintele D. Stăniloae, îl consideră pe acesta cel mai mare teolog al secolului al XXlea ${ }^{5}$. Din acest punct de vedere, Kallistos Ware apreciază deschiderea spre Occident a Ortodoxiei româneşti şi îşi exprimă preferinţa pentru viziunea echilibrată a părintelui Stăniloae ${ }^{6}$.

Teologia părintelui Stăniloae e numită patristică deoarece are ca izvoare fundamentale operele Sfinţilor Părinţi, începând de la Origen, Părinţii capadocieni, Atanasie, Chiril al Alexandriei, Evagrie, Maxim, Ioan Damaschin, Simeon Noul Teolog şi mulţi alţii, până la Grigorie Palama, scrierile acestuia din urmă fiind poarta de intrare a părintelui Stăniloae în viziunea teologică a Părinţilor Bisericii ${ }^{7}$. Această teologie patristică e numită şi filocalică, deoarece scrierile acestor Părinţi constituie cele 12 volume ale Filocaliei, traduse, comentate şi publicate de părintele Stăniloae, fiind cea mai completă colecţie de texte filocalice apărută până astăzi în lumea ortodoxă ${ }^{8}$.

contemporană, în ***, Persoană şi comuniune. Prinos de cinstire Preotului Profesor Academician Dumitru Stăniloae la împlinirea vârstei de 90 de ani, coord. Pr. Prof. Dr. Mircea Păcurariu şi Diac. Asist. Ioan I. Ică jr., Sibiu, Edit. Arhiepiscopiei Ortodoxe Sibiu, 1993, pp. 359-385; Grigore - Dinu Moş, Teorii privind occidentalizarea, înstrăinarea şi dubla pseudomorfoză a Ortodoxiei, în ***, Omagiu Părintelui Profesor Universitar Doctor Ioan I. Ică, Cluj Napoca, Edit. Renaşterea, 2007, pp. 262- 285.

5 † IPS Dr. Laurenţiu Streza, Elemente de teologie liturgică în gândirea Părintelui Dumitru Stăniloae, în ***, Dumitru Stăniloae (1903-1993). Teologie românească de dimensiune europeană, coord. IPS Dr. Laurenţiu Streza, Jürgen Henkel, Gheorghe F. Anghelescu, Sibiu, Edit. Schiller, 2008, p. 33.

${ }^{6}$ Grigore-Dinu Moş, op. cit., p. 280.

${ }^{7}$ Sf. Grigorie Palama este primul Părinte tradus şi studiat de Stăniloae, care a publicat în 1938, la Sibiu, volumul „Viaţa şi învăţătura Sf. Grigorie Palama, cu cele trei tratate".

${ }^{8}$ Volumele I-IV au apărut la Sibiu, între anii 1946-1948, iar volumele V-XII au apărut la Bucureşti, între anii 1976-1991. 
Încă de la primul contact cu lumea teologică, părintele Stăniloae a fost dezamăgit de învăţământul teologic, scolastic şi raţionalist, abandonând pentru o vreme teologia în favoarea filologiei. Părintele mărturiseşte: „Ceea ce am învăţat de la Sf. Grigorie Palama îmi confirmă insuficienţa dogmaticii scolastice, învăţată în timpul studiilor la facultatea de teologie, dogmatică redusă la definiţii despre un Dumnezeu distant, care nu-mi dădea dovada iubirii, coborând prin Fiul Lui la noi şi rămas prin Taine în noi”"

Lipsa acestei legături dintre teologie şi viaţă, dintre erudiţie şi evlavie era semnalată de mulţi teologi şi slujitori ai altarelor din acea vreme, sugerându-se, de către unii, chiar respingerea pregătirii teologice, nefolositoare vieţii duhovniceşti, căci „teologia savantă şi speculativă era o «proză rea»”"(Gala Galaction $)^{10}$. „Lumea nu are nevoie de preoţi «cu mintea hrănită de biblioteci», ci de preoţi «cu mintea lui Hristos». Astfel veţi fi «nori fară apă ce se poartă de vânturi şi copaci tomnatici neroditori, de două ori morţi şi dezrădăcinați»(Iuda 1,12) [...] Teologie fără teofilie şi fără filantropie!... Cea mai înfricoşătoare tragedie spirituală care ameninţă creştinătatea în zilele noastre!"'11. Era nevoia de a trăi integral credinţa şi parcă pregătirea teologică împiedica acest lucru, de aceea se afirma în acea vreme: „Biserica are nevoie de sfinţi, nu de cărturari şi farisei, de liniş̧ea serii, de roua dimineţii şi de cântatul cocoşilor"'2, adică de oameni care-L simt pe Dumnezeu şi se minunează de creaţia Lui, nu de oameni care teoretizează despre Dumnezeu.

9***, Omagiu memoriei Părintelui Dumitru Stăniloae, editor Arhim. Ioanichie Bălan, Iaşi, Edit. Mitropoliei Moldovei şi Bucovinei, 1994, p. 8.

${ }^{10}$ Pr. Prof. N. C. Buzescu, Preocupări teologice în jurnalul lui Galaction, în „ST”, anul XXVII, nr. 1-2, ianuarie-februarie, 1975, p. 22.

${ }^{11}$ Pr. prof. dr. Grigorie Cristescu, „Vino şi vezi!” Meditaţii, Sibiu, 1929, p. 310, apud Bogdan Aurel Teleanu, Metaforă şi misiune. Valorificarea literaturii laice în predica românească, Iaşi, Edit. Trinitas, 2007, pp. 345-346.

${ }^{12}$ Pr. prof. dr. Ion Bria, Al doilea botez. Itinerarele unei credinţe şi teologii de deschidere (Autobiografie), Alba Iulia, Edit. Reîntregirea, 2005, p. 67. 
Părintele Stăniloae nu a căzut în această extremă şi a căutat să se familiarizeze nu doar cu învăţătura Sfinţilor Părinţi, ci şi cu teologia şi filosofia occidentală, fiind un bun cunoscător al teologiei dialecticii protestante sau al existenţialismului francez. Datorită capacităţii sale extraordinare de sinteză, a reușit să pună în dialog viziunea teologică a Sfinţilor Părinţi cu gândirea teologică, filosofică şi culturală contemporană, aşa cum au făcut şi Părinţii Bisericii în vremea lor, realizând o ,paradoxală teologie dogmatică neo-patristică”"13. Teologul german Adolf Martin Ritter subliniază şi el unicitatea operei marelui teolog român. „Ceea ce se refuză comparaţiei este, la Părintele Stăniloae, puterea lui de sinteză, aşa cum apare în «Dogmatica» sa, cu siguranţă cea mai bună sinteză a teologiei dogmatice ortodoxe din câte au apărut în ultima vreme"14.

Prin viaţa şi opera sa, părintele a reuşit să unească teologia cu viaţa, scoţând în evidenţă importanţa spirituală a dogmelor Bisericii Ortodoxe şi, totodată, impactul lor asupra vieţii practice a creştinilor ${ }^{15}$. În Prefaţa „Dogmaticii” lui Andrutsos, tradusă în 1930, constata cu nemulţumire slăbirea legăturii dintre teologia şi spiritualitatea ortodoxă, iar în anul 1946, în Prefaţa Filocaliei, semnalează că spiritualitatea la rândul ei nu era suficient de orientată şi motivată teologic, nici nu avea reguli clare de progres duhovnicesc ${ }^{16}$.

${ }^{13}$ Andrew Louth, Dumitru Stăniloae şi teologia neo-patristică, în ***, Dumitru Stăniloae sau Paradoxul teologiei, coord. Teodor Baconsky şi Bogdan TătaruCazaban, Bucureşti, Edit. Anastasia, 2003, p. 133.

${ }^{14}$ Adolf Martin Ritter, În amintirea Părintelui Stăniloae, în ***, Părintele Dumitru Stăniloae în conştiinţa contemporanilor ..., p. 140.

${ }^{15}$ Părintele Stăniloae are mai multe studii în care accentuează această idee: Legătura între evlavie şi teologie în Biserica Ortodoxă, în „Mitropolia Olteniei”, anul XXXVI, nr. 1-2, ianuarie-februarie, 1984, pp. 47-56; Dogmele creştine şi apostolice, expresii ale binelui cel mai înalt, în „Ortodoxia”, anul XLIV, nr. 1-2, ianuarie-iunie, 1992, pp. 3-4, etc.

${ }^{16} \dagger$ P.F. Daniel, Teologia - ştiinţa mântuirii şi a vieţii veşnice în gândirea Părintelui Stăniloae, în ***, Dumitru Stăniloae (1903-1993). Teologie românească..., p. 23. 
Conform părintelui Kallistos Ware, răspunsul la această problemă teologică actuală l-a găsit la Sfinţii Părinţi, dar nu un răspuns ad-litteram, istoric sau repetitiv, ci profetic, actualizat, rezultat din înţelegerea ,în duh” a operelor patristice. Părintele Stăniloae a căutat să răspundă nu doar la întrebarea „Ce au spus Părinţii cu mult timp în urmă?”, ci mai ales „Ce ar spune Părinţii dacă ar trăi astăzi?”. Altfel spus, părintele a căutat nu doar „exactitatea arheologică”, ci „,anamneza pnevmatică”. „Noi căutăm să prezentăm nu doar litera Părinţilor, ci spiritul lor vital, mintea sau phronema lor, adică ceea ce a fost numit tinereţea lor veşnică" ${ }^{17}$.

Acest demers teologic, existențial, îl prezintă cel mai bine însuşi părintele:

„Ca student şi ca tânăr profesor, m-am îndreptat spre mulţi profesori şi cărţi. De la fiecare am câş̧tigat câte ceva, dar după o vreme am depăşit ceea ce socoteam că nu e în stare să mă ajute în înţelegerea şi experienţa lui Dumnezeu într-un mod convingător. Sfinţii Părinţi au fost cei care miau revelat profunzimile autenticei înţelegeri a lui Dumnezeu şi căldura vieţii în El. Teologia şi filosofia pe care le-am studiat în tinereţe mi-au dat sensibilitatea curentă pentru a exprima modul de a înţelege şi a trăi al Părinţilor. $\mathrm{Cu}$ aceeaşi teologie şi filozofie am devenit conştient de problemele ce confruntă astăzi credinţa creştină şi pentru care căutam răspunsurile la Părinţi. I-am găsim concentraţi într-un mod intim şi virtual, mai degrabă decât într-o formă concretă, pe problemele omului contemporan. M-am convins că există unitate organică între gândirea patristică şi gândirea ce trebuie să răspundă problemelor actuale. Întradevăr, gândirea Părinţilor este nemuritoare"18.

În Prefaţa la prima ediţie a Teologiei Dogmatice Ortodoxe, părintele Stăniloae afirmă că ,a părăsit metoda scolastică a tratării dogmelor ca propoziţii abstracte, de un interes pur teoretic şi în

\footnotetext{
${ }^{17}$ Kallistos Ware, art. cit., p. 49.

${ }^{18}$ F. Strazzari - L. Prezzi (Edit.), „Una teologia filocalica. Intervista a padre Dumitru Stăniloae, Il regno-attualità 34 (1989), p. 107, apud P. Maciej Bielawski, OSB, Părintele Dumitru Stăniloae, o viziune filocalică despre lume, trad. diac. Ioan I. Ică jr., Sibiu, Edit. Deisis, 1998, pp. 76-77.
} 
mare măsură depăşit, fără legătură cu viaţa adâncă, duhovnicească a sufletului"'19. Apoi prezintă noua sa interpretare a dogmelor, care se dovedeşte a fi un veritabil şi pertinent răspuns teologic la problemele actuale ale societăţii.

„Ne-am condus în această străduință de modul în care au înţeles învăţătura Bisericii Sfinţii Părinţi de odinioară, dar am ţinut seama în interpretarea de faţă a dogmelor şi de necesităţile spirituale ale sufletului care-şi caută mântuirea în timpul nostru, după trecerea prin multe şi noi experienţe de viaţă, în cursul atâtor secole care ne despart de epoca Sfinţilor Părinţi. Ne-am silit să înţelegem învăţătura Bisericii în spiritul Părinţilor, dar în acelaşi timp să o înţelegem aşa cum credem că ar fi înţeles-o ei astăzi. Căci ei n-ar fi făcut abstracție de timpul nostru, aşa cum n-au făcut de al lor"20.

În teologia Sfinţilor Părinţi, dar şi în cea a părintelui Stăniloae, găsim nota fundamentală a Ortodoxiei autentice: viaţa personală este în deplină concordanţă cu opera. În ,,Spiritualitate şi comuniune în Liturghia ortodoxă" părintele analizează raportul dintre experienţa personală a lui Dumnezeu, sublimată în cadrul jertfei euharistice a comunităţii eclesiale, şi prezentarea teologică a adevărurilor de credinţă. „Când experienţa nu e a lui proprie, ci a altuia, teologul care face reflexiuni asupra ei, face o teologie moartă"21, deoarece e străin de Dumnezeu. Regula teologică a părintelui este esenţială: „Teologul redă această experienţă când o redă ca experienţă proprie; teologia lui e vie atunci şi ea"22. Altfel spus, teologia e vie când şi experienţa spirituală e vie şi reală, acestea fiind într-o relaţie de complementaritate. „Teologia adânceşte experienţa a ceea ce se întâmplă în Sfânta Liturghie, în sensurile ce le găseşte în ea, iar experienţa lui Dumnezeu

\footnotetext{
${ }^{19}$ Pr. Prof. Dumitru Stăniloae, Teologia Dogmatică Ortodoxă, vol. I, Bucureşti, EIBMBOR, 2003, p. 5.

${ }^{20}$ Ibidem, pp. 5-6.

${ }^{21}$ Pr. Prof. Dumitru Stăniloae, Spiritualitate şi comuniune în Liturghia ortodoxă, Bucureşti, EIBMBOR, 2004, p. 15.

${ }^{22}$ Ibidem.
} 


\section{Alexandru TEOMPA}

Cel în Treime dă viaţă teologiei şi o adânceşte la rândul ei”23.

Viaţa părintelui Stăniloae a fost una ascetică, indiferent de condiţiile exterioare sau de regimul politic. A trăit la fel de auster toată viaţa sa, atât în perioada cât a fost rector al Academiei Teologice de la Sibiu (1936-1946), cât şi după ce a ieşit din închisoare şi a reprezentat teologia românească în străinătate, sau în perioada de libertate de după 1989. Ucenicii săi dau mărturie în acest sens. ,Biroul său era cât o chilie. Dânsul avea foarte multe din calităţile monahului, deşi era căsătorit. În primul rând, impresiona modestia foarte evidentă a locuinţei sale"24. Era un om al rugăciunii, atât el, cât şi soţia sa, Maria. Părintele chiar afirma: „„SSoţia mea se roagă mai mult decât mine». Iar ea răspundea: «Ei, zice Dumitru aşa, dar dânsul şi când scrie, se roagă». Era între ei o comuniune spirituală profundă, întărită de rugăciune"25.

Itinerarul vieţii părintelui a fost presărat cu multe încercări, care i-au marcat profund viaţa, dar din care a ieşit mai puternic din punct de vedere spiritual, iar aceste momente au devenit ,forme de mărturisire care dublează şi potenţează opera"26 marelui teolog. Un astfel de moment a fost perioada de aproape 5 ani de detenţie (1958-1963), despre care părintele a vorbit rareori şi extrem de puţin ${ }^{27}$, numind-o, cu adâncă modestie, perioada ,când şi-a purtat pur şi simplu crucea"28. Va mărturisi însă că acolo a învăţat să se roage cu adevărat, căci

\section{${ }^{23}$ Ibidem}

$24 \dagger$ Daniel, Mitropolitul Moldovei şi Bucovinei, Părintele Stăniloae, om şi teolog al rugăciunii, în ***, Părintele Dumitru Stăniloae în conștiința contemporanilor..., p. 26.

${ }^{25}$ Ibidem, p. 28.

${ }^{26}$ Dan Ciachir, Omul şi lucrarea sa, în ***, Părintele Dumitru Stăniloae în conștiința contemporanilor..., p. 187.

${ }^{27}$ Dumitru Stăniloae, Prigonirea Bisericii Ortodoxe strămoşeşti sub comunism, în „Ortodoxia”, anul XLII, nr. 1, ianuarie-martie, 1990, pp. 197-200.

${ }^{28}$ Olivier Clemént, Geniul Ortodoxiei, în ***, Dumitru Stăniloae sau Paradoxul teologiei..., p. 30 . 
„închisoarea a devenit pentru el o şcoală a rugăciunii"”29. Aceşti ani de suferinţe inimaginabile nu constituie o perioadă de regres academic, ci una de aprofundare a credinţei, de coborâre a minţii în inimă şi de exersare a unei teologii vii, existenţiale, diferită de aceea de la catedră sau de la amvon, căci temniţa i-a devenit o ,şcoală a teologiei”. Prin aceasta s-a asemănat Sfântului Pavel, cel mai mare misionar creştin, vestindu-L şi în temniţă pe Hristos, ,,pentru Care a suferit până şi lanţuri ca un făcător de rele”, dar arătând că „,cuvântul lui Dumnezeu nu se leagă" niciodată (II Tim. 2, 9).

În centrul teologiei părintelui Stăniloae stă persoana, care 1-a fascinat toată viaţa şi despre care marele teolog a scris pagini memorabile. „În cărţile mele am meditat îndelung la taina persoanei. Chiar şi în cazul omului, taina persoanei cuprinde o bogăţie nesfârşită. Niciodată nu poate fi definită, totdeauna are ceva de spus, cred că în veci are ceva de spus!" 30 Părintele ne-a readus la gândirea de odinioară a Părinţilor Bisericii, care vedeau cunoaşterea lui Dumnezeu doar în baza unui dialog interpersonal, a unei relaţii de iubire, după modelul comuniunii Persoanelor Sfintei Treimi. Cunoaşterea lui Dumnezeu este ,cunoaşterea Lui ca realitate personală. Iar cunoaşterea aceasta este totdeauna o relaţie iubitoare. Numai iubind pe Dumnezeu şi numai având conştiinţa că e iubit de Dumnezeu, omul înaintează într-o viaţă de care nu se satură niciodată" ${ }^{\prime \prime}$.

Dogma trinitară, văzută deseori ca o formulă abstractă, intangibilă

$29 \dagger$ Daniel, Mitropolitul Moldovei şi Bucovinei, Părintele Stăniloae, om şi teolog al rugăciunii, în ***, Părintele Dumitru Stăniloae în conștiința contemporanilor..., p. 32.

${ }^{30}$ D. Stăniloae, Sf. Grigorie de Nazianz sau ce înseamnă a fi teolog, Fragmente din intervenţia ţinută cu prilejul lansării traducerii celor „Cinci Cuvântări teologice" ale Sf. Grigorie de Nazianz, (Anastasia, 1993), în cadrul serilor Darvari, organizate de Fundaţia Anastasia, în ***, Dumitru Stăniloae sau Paradoxul teologiei..., p. 24.

${ }^{31}$ Dumitru Stăniloae, Chipul nemuritor al lui Dumnezeu, Bucureşti, Edit. Basilica, 2013, pp. 26-27. 


\section{Alexandru TEOMPA}

şi incomprehensibilă, accesibilă doar ,specialiştilor”, devine, prin Dumitru Stăniloae, un model de convieţuire creştină, un model social. In toată opera părintelui găsim această raportare la paradigma trinitară. „Credinţa creştină afirmă că Sfânta Treime e baza eternă a persoanelor umane şi modelul de fericire în unitatea dragostei”32.

Părintele a scris în perioada în care omul ca entitate personală nu conta, ci doar colectivitatea care asigura progresul şi dăinuirea speciei umane. El vorbeşte despre om ca persoană împlinită doar în relaţia de iubire, în comuniune, în sobornicitate şi frăţietate, respingând individualismul anarhic şi colectivismul anulator de personalitate ${ }^{33}$. „În felul acesta de a rezolva raportul dintre ins şi societate se răsfrânge şi dogma Sfintei Treimi. De obicei, omul caută să vieţuiască după cum crede că vieţuieşte Dumnezeu în care crede" 34 .

Modelul de devenire a persoanei umane este Dumnezeu-Omul Iisus Hristos, Care ,întrupându-se, S-a apropiat de noi, ajutându-ne să facem experienţa lui Dumnezeu ca a unei persoane în comuniune directă cu noi"35. Prin El, omenirea a ,pătruns” în sânul Dumnezeirii iar ,moartea Lui Jertfelnică e cea mai mare coborâre a Lui la noi, în timp, şi cea mai mare apropiere a Lui ca om de Tatăl"36. Coborârii Lui la noi îi corespunde ridicarea noastră la Dumnezeu, prin ceea ce părintele numeşte: „Drumul cu Hristos Mântuitorul prin Tainele şi Sărbătorile Bisericii Ortodoxe"'37, adică persoana umană, integrată

${ }^{32}$ D. Stăniloae, Spiritualitate..., p. 18.

${ }^{33}$ Dumitru Stăniloae, Biserica şi unitatea neamului, în Dumitru Stăniloae, Ortodoxie şi naţionalism, Bucureşti, 2011, p. 132.

${ }^{34}$ D. Stăniloae, Ortodoxie şi românism, Bucureşti, Edit. Basilica, 2014, p. 72.

${ }^{35}$ D. Stăniloae, Iisus Hristos sau restaurarea omului, Bucureşti, Edit. Basilica, 2013, pp. 315-316.

${ }^{36}$ Dumitru Stăniloae, Chipul nemuritor al lui Dumnezeu, Bucureşti, Edit. Basilica, 2013, p. 374.

${ }^{37}$ D. Stăniloae, Drumul cu Hristos Mântuitorul prin Tainele şi Sărbătorile Bisericii Ortodoxe, în „Ortodoxia”, nr. 2, 1976, pp. 402-416, apud Pr. prof. dr. Kostantinos Karaisaridis, Referințe liturgice în opera Părintelui Dumitru 
în comunitatea eclesială, parcurge în sens invers, prin harul Sfintelor Taine şi bucuria tainică a sărbătorilor creştine, drumul prin care Mântuitorul Hristos ne-a unit cu Tatăl, căci „Biserica este Împărăţia lui Dumnezeu pe pământ, în care noi ca membri călătorim mereu spre Tatăl pe calea numită Hristos" ${ }^{\prime 3}$.

Înainte de orice, părintele este teologul iubirii şi al bucuriei creştine, pe care le-a „cântat” toată viaţa sa, prin ceea ce a trăit, a simţit, a scris şi a transmis. „Ortodoxia, prin bucuria trăirii lui Dumnezeu, este doxologică, nu teoretică [...] participare la existență alături de întreaga

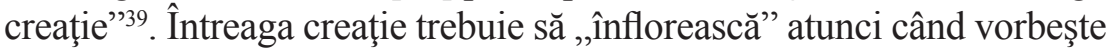
despre Dumnezeu. Sfântului Francisc de Assisi îi e atribuit un poem: „M-am întâlnit cu migdalul şi i-am spus/ frate, vorbește-mi despre Dumnezeu!/ şi migdalul a înflorit...”40. La interpelarea lumii actuale cu privire la Dumnezeu, părintele Stăniloae „a înflorit” o teologie mărturisitoare, o provocare pentru omul, tot mai zbuciumat şi mai lipsit de repere, al mileniului III. În perioada în care mulţi păstori de suflete şi creştini râvnitori respingeau pregătirea teologică scolastică şi aridă, părintele Stăniloae ,a îmbrăcat limbajul teologic în haine de sărbătoare" ${ }^{41}$, creând „o dogmatică pentru omul de azi" ${ }^{42}$.

Stăniloae, în ***, Dumitru Stăniloae (1903-1993). Teologie..., p. 225.

${ }^{38}$ Pr. Lect. Univ. Dr. Mihai Himcinschi, Relaţia Duhului Sfânt cu Tatăl şi cu Fiul in teologia răsăriteană şi apuseană. Implicatiile doctrinare şi spirituale ale acesteia, Alba Iulia, 2002, p. 296.

${ }^{39}$ Some characteristics of Orthodoxy, în „Sobornost” 5:9, 1969, p. 628, citat de episcopul Kallistos: E, xxii, apud Andrew Louth, art. cit., p. 152.

${ }^{40} \mathrm{Pr}$. Doru Costache, Colocviul fără sfârşit. Rațiunea de a fi a creației în gândirea Părintelui Dumitru Stăniloae, în ***, Dumitru Stăniloae sau Paradoxul teologiei..., p. 225.

${ }^{41}$ Pr. Ion Bria, Ortodoxia în Europa - Locul spiritualităt̆ii române, Iaşi, Edit. Mitropoliei Moldovei şi Bucovinei, 1995, p. 100.

${ }^{42}$ Dr. Dan-Ilie Ciobotea, O dogmatică pentru omul de azi, în „,ST”, anul XXXVII, nr. 6, 1986, pp. 98-104, apud Prof. Dr. Ion Bria, Părintele Stăniloae - un teolog creator şi mărturisitor in acelaşi timp, în ***, Părintele Dumitru Stăniloae în conștiința contemporanilor..., p. 195. 
Părintele a revalorificat moştenirea teologică a Bisericii, arătând că dogmele nu sunt nişte formulări pur teoretice, abstracte şi aride, fără nici o rezonanţă în viaţa concretă, ci ele dau sens şi profunzime spiritualităţii, sunt mărturisite în stare de rugăciune în cadrul cultului divin şi devin răspunsuri vii, pertinente, $\mathrm{cu}$ o forţă misionară extraordinară, la problemele actuale ale societăţii. $\mathrm{O}$ astfel de teologie devine stare de rugăciune şi de uimire, revărsare de har şi bucurie, care inundă sufletul omului şi care trece, prin iradiere, în sufletul celorlalţi, ca o mărturie veritabilă a unei vieţi autentice împreună cu Dumnezeu.

\section{Bibliografie}

1. ***, Dumitru Stăniloae (1903-1993). Teologie românească de dimensiune europeană, coord. IPS Dr. Laurenţiu Streza, Jürgen Henkel, Gheorghe F. Anghelescu, Sibiu, Edit. Schiller, 2008.

2. ***, Dumitru Stăniloae sau Paradoxul teologiei, coord. Teodor Baconsky şi Bogdan Tătaru-Cazaban, Bucureşti, Edit. Anastasia, 2003.

3. ***, Omagiu memoriei Părintelui Dumitru Stăniloae, editor Arhim. Ioanichie Bălan, Iaşi, Edit. Mitropoliei Moldovei şi Bucovinei, 1994.

4. ***, Omagiu Părintelui Profesor Universitar Doctor Ioan I. Icăa, Cluj Napoca, Edit. Renaşterea, 2007.

5. ***, Părintele Dumitru Stăniloae în conștiința contemporanilor. Mărturii, evocări, amintiri, Iaşi, Edit. Trinitas, 2003.

6. ***, Persoană şi comuniune. Prinos de cinstire Preotului Profesor Academician Dumitru Stăniloae la împlinirea vârstei de 90 de ani, coord. Pr. Prof. Dr. Mircea Păcurariu şi Diac. Asist. Ioan I. Ică jr., Sibiu, Edit. Arhiepiscopiei Ortodoxe Sibiu, 1993.

7. Bielawski, P. Maciej, OSB, Părintele Dumitru Stăniloae, o viziune filocalică despre lume, trad. diac. Ioan I. Ică jr., Sibiu, Edit. Deisis, 1998.

8. Bria, Ion, Ortodoxia în Europa - Locul spiritualităţii române, Iaşi, Edit. Mitropoliei Moldovei şi Bucovinei, 1995.

9. Idem, Al doilea botez. Itinerarele unei credinţe şi teologii de deschidere (Autobiografie), Alba Iulia, Edit. Reîntregirea, 2005.

10. Buzescu, N. C., Preocupări teologice în jurnalul lui Galaction, în „ST”, anul XXVII, nr. 1-2, ianuarie-februarie, 1975.

11. Himcinschi, Mihai, Relaţia Duhului Sfânt cu Tatăl şi cu Fiul 
in teologia răsăriteană şi apuseană. Implicaţiile doctrinare şi spirituale ale acesteia, Alba Iulia, 2002.

12. Stăniloae, Dumitru, Prigonirea Bisericii Ortodoxe strămoşeşti sub comunism, în „Ortodoxia”, anul XLII, nr. 1, ianuarie-martie, 1990.

13. Idem, Iisus Hristos sau restaurarea omului, Bucureşti, Edit. Basilica, 2013.

14. Idem, Ortodoxie şi românism, Bucureşti, Edit. Basilica, 2014.

15. Idem, Chipul nemuritor al lui Dumnezeu, Bucureşti, Edit. Basilica, 2013.

16. Idem, Ortodoxie şi naţionalism, Bucureşti, 2011.

17. Idem, Dogmele creştine şi apostolice, expresii ale binelui cel mai inalt, în „Ortodoxia”, anul XLIV, nr. 1-2, ianuarie-iunie, 1992.

18. Idem, Legătura între evlavie şi teologie în Biserica Ortodoxă, în „Mitropolia Olteniei”, anul XXXVI, nr. 1-2, ianuarie-februarie, 1984.

19. Idem, Spiritualitate şi comuniune în Liturghia ortodoxă, Bucureşti, EIBMBOR, 2004.

20. Idem, Teologia Dogmatică Ortodoxă, vol. I, Bucureşti, EIBMBOR, 2003.

21. Teleanu, Bogdan Aurel, Metaforă şi misiune. Valorificarea literaturii laice în predica românească, Iaşi, Edit. Trinitas, 2007. 
